\title{
Osmotic properties of boar spermatozoa and their relevance to cryopreservation
}

\author{
J. A. Gilmore ${ }^{1,2}$, Junying $\mathrm{Du}^{\mathrm{I}}$, Jun $\mathrm{Tao}^{\mathrm{I}}, \mathrm{A}$. T. Peter ${ }^{2}$ and \\ J. K. Critser ${ }^{1,2,3}{ }^{*}$ \\ ${ }^{1}$ Cryobiology Research Institute, Methodist Hospital of Indiana, Inc., Indianapolis, IN 46202, USA, \\ ${ }^{2}$ Department of Veterinary Clinical Sciences, School of Veterinary Medicine, Purdue University, \\ West Lafayette, IN 47907, USA; and ${ }^{3}$ Departments of Physiology/Biophysics and Obstetrics/Gynecology, \\ Indiana University School of Medicine, Indianapolis, IN 46202, USA
}

\begin{abstract}
A series of six experiments was conducted to determine the fundamental cryobiological properties of boar spermatozoa to develop optimal approaches for cryopreserving this important cell type. In the first experiments, boar spermatozoa samples were diluted in various osmolalities of experimental solutions (185-900 mOsmol kg ${ }^{-1}$ ) to provide hypo-, iso-, and hyperosmotic conditions. Equilibrium cell volumes (Expts 1 and 2) were measured after exposure for $3 \mathrm{~min}$ and the change in cell volume was measured over time using an electronic particle counter (Expt 3). The isosmotic cell volume was found to be $26.3 \pm 0.39 \mu \mathrm{m}^{3}$ (mean $\pm \mathrm{SEM} ; n=5$ ). Over this range of osmolalities, boar spermatozoa behaved as linear osmometers (a linear volume versus $1 /$ osm plot, $r^{2}=0.99$ ) with an osmotically inactive cell fraction of $67.4 \pm 4.5 \%$. The rate of water permeability $\left(L_{p}\right)$ was determined to be $1.03 \pm 0.05 \mu \mathrm{m} \mathrm{min}^{-1}$ atm $^{-1}$, which was consistent within and among donors $(P>0.130)$. A second series of experiments was performed to determine the effect of temperature and osmolality on boar sperm motility (Expt 4), and the effect of osmolality on the integrity of the sperm plasma membrane and its temperature dependence. Plasma membrane integrity was measured before and after boar spermatozoa were returned to an isosmolality (Expt 6). Motility was not affected at $30^{\circ} \mathrm{C}$, relative to that at room temperature, but was significantly decreased $(P<0.05)$ at $8^{\circ} \mathrm{C}$ and $0^{\circ} \mathrm{C}$ (yielding a relative reduction to $85 \%$ and $35 \%$ of original motility, respectively; $n=6$ ). Sperm motility was not significantly decreased $(P>0.05)$ until the osmolality reached $210 \mathrm{mOsmol} \mathrm{kg}^{-1}$, at which time motility began to decrease from $95 \%$ to $10 \%$ of the original value at $90 \mathrm{mOsmol} \mathrm{kg}{ }^{-1}$. The integrity of the plasma membrane of boar spermatozoa was found to be dependent on temperature, donor and osmolality, decreasing significantly $(P<0.05)$ below room temperature, and below $185 \mathrm{mOsmol} \mathrm{kg}{ }^{-1}(P<0.05)$. There was no significant difference $(P>0.10)$ in the integrity of the plasma membrane of the samples before and after returning to

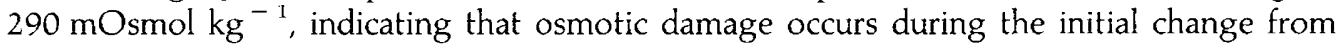
isosmotic to hyposmotic media. These osmotic characteristics could be used to determine optimal conditions for cryopreservation of boar spermatozoa.
\end{abstract}

\section{Introduction}

The importance of the use of boar semen for artificial insemination (AI), leading to the development of successful techniques using fresh boar spermatozoa, was first recognized by Ito et al. (1948) and Polge (1956). Since then, pork production has increased in commercial and economic value worldwide, and as a result, the need for cryopreserved boar semen for AI is becoming greater, especially in Europe and other countries where there is a strong financial drive to raise specific swine

*Correspondence.

Received 8 August 1995. breeds. The majority of cryopreserved boar semen is processed in North America and more than $50 \%$ is exported (Pond et al., 1991).

Once cryopreservation is optimized, more options for the management of swine reproduction will become available. The ability to enhance the distribution and preservation of pig lines that have desirable genetic characteristics will become feasible worldwide (Reed, 1985). Cryopreserved boar semen could be imported and exported, eliminating the barriers of transporting the animals themselves or the problem of short lived viability of extended semen. Most importantly, cryopreserved boar semen would allow for the time required for infectious disease testing and provide a means of storing semen from specific 
boars in two different locations in the event of disease outbreak or other issues that may occur at one location.

Although cryopreserved boar semen is agriculturally and financially important, there is no widely accepted, successful procedure for cryopreservation. With current techniques, there is generally only a $30-40 \%$ cryosurvival rate of boar spermatozoa, and a loss of fertility in frozen semen versus fresh semen (Polge, 1956; Johnson et al., 1981). Attempts have been made to improve methods for freezing boar semen. Pursel and Johnson (1975) developed a pelleting method for cryopreservation and Westendorf et al. (1975) repeated similar findings using $6 \mathrm{ml}$ straws for freezing boar semen. However, each method uses its own set of cryobiological problems in terms of sperm survival (Hofmo and Almlid, 1991) and therefore, as the need for cryopreserved boar spermatozoa increases, this decrease in sperm function becomes a more evident problem. For an improvement in cryopreservation of boar semen, knowledge is needed of the physical and biophysical properties of the spermatozoa and how these characteristics are affected during the stages of cryopreservation.

Cryopreservation places osmotic stress upon the cells. Knowledge of the permeability of the boar sperm plasma membrane to water and the subsequent change in cell volume, is required to minimize this stress. While the cell parameters necessary for the development of optimal methods of cryopreservation have been studied in spermatozoa of other species, there have been few studies on the osmotic parameters of boar spermatozoa. Hammerstedt et al. (1978), using electron paramagnetic resonance (EPR), and O'Donnell (1969), using an electronic particle counter, were the first to determine the isosmotic cell volume of boar spermatozoa. Du et al. (1994) investigated the osmotic response of boar spermatozoa using EPR. Hydraulic conductivity, the critical osmolality at which $50 \%$ of the cells swell and lyse, osmotic effects, and other factors affecting the viability of boar spermatozoa and response to osmotic change need to be determined to broaden our understanding of cryopreservation of boar spermatozoa.

The objectives of the study reported here were to: (I) determine the isosmotic cell volume $\left(V_{\text {iso }}\right)$ of boar spermatozoa, (2) determine the osmotically inactive fraction $\left(V_{\mathrm{b}}\right)$ of the cells and confirm a linear osmotic response, (3) measure the hydraulic conductivity of the spermatozoa $\left(L_{\mathrm{p}}\right),(4)$ investigate the effects of osmolality and temperature on sperm motility, (5) determine the effect of osmolality on the integrity of the plasma membrane of boar spermatozoa and its temperature dependence, and (6) compare the integrity of the plasma membrane of boar spermatozoa after anisosmotic treatment before and after their return to an isosmotic condition.

\section{Materials and Methods}

\section{Animals}

Five (Expts 1, 2 and 3), six (Expts 4 and 6), or seven (Expt 5) mature Yorkshire boars (18 months to 3 years old, weighing 204 to $273 \mathrm{~kg}$ ) were used in this study. The boars were fed once a day with a mixed corn-soybean ration according to each boar's body condition and were allowed free access to water. The boars could move inside a barn with straw or outside on a concrete slab at will.

\section{Media}

The media used were derivatives of a Tyrodes' lactate Hepes (TL Hepes) buffered solution (285 $\mathrm{mOsm} \mathrm{kg}^{-1}$ ) (Bavister et al., 1983). In Expts 2 and 3, the media were diluted with distilled water to make a hyposmotic solution: $185 \mathrm{mOsmol} \mathrm{kg}^{-1}$ and two hyperosmotic solutions were made by diluting $1 \mathrm{~mol}$ sucrose $\mathrm{l}^{-1}$ with isosmotic TL Hepes: (1) $600 \mathrm{mOsmol} \mathrm{kg}{ }^{-1}$, and (2) $900 \mathrm{mOsmol} \mathrm{kg}^{-1}$. In Expts 4, 5 and 6, various hypo-, iso- and hyperosmotic media were made from $\mathrm{NaCl}$ derivatives with final osmolalities ranging from 90 to $1445 \mathrm{mOsmol} \mathrm{kg}^{-1}$. Osmolality was determined using a freezing-point depression osmometer (Model 3D2: Advanced Instruments, Needham Heights, MA) and osmolalities were accurate to $\pm 5 \mathrm{mOsmol}$ $\mathrm{kg}^{-1}$. All media used in the experiments were obtained from Sigma Chemical Co. (St Louis, MO).

\section{Samples}

Semen samples were collected by manual manipulation using a dummy and gloved hand. Semen from the sperm-rich portion was diluted $1: 3$ or $1: 2$ times in TL Hepes media in $15 \mathrm{ml}$ conical tubes (Sarstedt, Newton, NC) and transported in a $37^{\circ} \mathrm{C}$ water bath during the $1 \mathrm{~h}$ transport time. Five microlitres of the sample were analysed using computer-assisted semen analysis (CASA) (Cell Soft ${ }^{\mathrm{k}}$, Version 3.2/C, CRYOResources, LTD, Montgomery, NY) to determine the concentration and percentage motility as described by Massanyi (1989). An additional CASA analysis was performed at the completion of each experiment. Owing to the requirements of the Coulter counter data analysis for clean sample preparation, in Expts 1, 2 and 3, semen samples were processed further by a discontinuous $(90 \%$ and $47 \%$ ) Percoll gradient separation method and washed with TL Hepes to remove excess debris.

\section{Flow cytometry}

The integrity of the sperm plasma membrane was determined by Hoechst stain 33258 (H258) (Sigma) (Tao et al., 1993). After the spermatozoa were exposed to various osmotic solutions (total volume $=800 \mu \mathrm{l}$ ) for $5 \mathrm{~min}, 5 \mu \mathrm{l}$ of $\mathrm{H} 258$ (final concentration, $0.1 \mu \mathrm{g} \mathrm{ml}^{-1}$ ) were added to each sperm suspension and mixed thoroughly. After $5 \mathrm{~min}, 30 \mu \mathrm{l}$ salmon testis DNA (STDNA; Sigma; stock solution: $10 \mathrm{mg} \mathrm{ml}^{-1}$ ) was added to remove the unbound $\mathrm{H} 258$ from the suspension. A FACStar Plus Flow Cytometer (Becton Dickinson, San Jose, CA) was used to quantify $\mathrm{H} 258$ staining using a $3 \mathrm{~W}$ krypton light source running at $200 \mathrm{~mW}$ multiline UV (350 nm) and a barrier filter 450DF65. Instrument alignment was performed each day with fluorescent microbead standards to standardize sensitivity and set-up. Unstained spermatozoa were used for adjustment of the photomultiplier settings, and electronic compensation was adjusted for spectral overlap with individually stained spermatozoa. For each sample, at least approximately 5000 spermatozoa were analysed and the percentage of cells stained 
Table 1. Definitions of major symbols used in equations

\begin{tabular}{|c|c|c|c|}
\hline Symbol & Description & Units & Value \\
\hline$L_{\mathrm{p}}$ & Water permeability & $\mu \mathrm{m} \min ^{-1} \mathrm{~atm}^{-1}$ & Parameter \\
\hline$A_{c}$ & Surface area of boar spermatozoa & $\mu \mathrm{m}^{2}$ & 156 \\
\hline$V_{\mathrm{b}}$ & Osmotically inactive cell volume & $\mu \mathrm{m}^{3}$ & $67 \%$ \\
\hline$V_{\mathrm{s}}$ & Total cell solids & $\mu \mathrm{m}^{3}$ & $57 \%$ \\
\hline$V^{s}$ & Total cell volume & $\mu \mathrm{m}^{3}$ & 26.6 \\
\hline$M$ & Osmolality & osm kg ${ }^{-1} \mathrm{H}_{2} \mathrm{O}$ & - \\
\hline C & Concentrations & Molal & Variable \\
\hline iso, salt & Subscripts (iso $=$ isomolality, salt $=$ impermeable salts) & - & - \\
\hline $\mathrm{e}, \mathrm{i}$ & Superscripts $(\mathrm{e}=$ external, $\mathrm{i}=$ internal) & - & - \\
\hline$\vec{V}$ & Partial molar volume & $1 \mathrm{~mol}^{-1}$ & Variable \\
\hline
\end{tabular}

was measured. The H258-negative cells were considered to be membrane-intact cells (Tao et al., 1993).

\section{Electronic particle counter}

A Coulter Counter (ZM model, Coulter Electronics, Inc., Hialeah, FL), with a standard $50 \mu \mathrm{m}$ aperture tube was used for all measurements. Sperm cell volume was calibrated using spherical styrene beads (Duke Scientific Corporation, Palo Alto, CA) with a diameter of $3.98 \pm 0.03 \mu \mathrm{m}$ (mean \pm SEM) and a volume of $33.1 \mu^{3}$.

\section{Data acquisition}

The electronic particle counter was interfaced to a microcomputer using a CSA-1 interface (The Great Canadian Computer Company, Edmonton, Alberta). Static and kinetic volume measurements were made using separate software programs as described by Gilmore et al. (1995).

\section{Statistical analysis}

Data were analysed using standard analysis of variance approaches (Steel and Torrie, 1960) with the SAS ${ }^{\mathbb{N}}$ program (SAS Institute Inc., Cary, NC). The mean, standard error and coefficient of variation were computed within and among donors.

\section{Experimental design}

Experiment 1: determination of isosmotic cell volume of boar spermatozoa. A suspension of cells was prepared and $100 \mu \mathrm{l}$ of the sample were abruptly diluted into $10 \mathrm{ml}$ of isosmotic TL Hepes media $\left(285 \mathrm{mOsmol} \mathrm{\textrm {kg } ^ { - 1 }}\right.$ ). The cells were allowed to equilibrate for $3 \mathrm{~min}$ and mean cell volumes were measured in triplicate at $22^{\circ} \mathrm{C}$ using an electronic particle counter. Samples from five boars were measured.

Experiment 2: cell osmotic response and inactive cell volume $\left(\mathrm{V}_{b}\right)$. This experiment was designed to investigate whether boar spermatozoa act as linear osmometers and to determine the osmotically inactive fraction of cell volume $(n=5)$. After the cells were processed, $100 \mu \mathrm{l}$ of the sperm suspension was abruptly diluted into experimental solutions of 185900 mOsmol $\mathrm{kg}^{-1}$ at $22^{\circ} \mathrm{C}$. The samples were allowed to equilibrate for $3 \mathrm{~min}$ and the mean static cell volume was measured from histograms of volume distributions. Kinetic volume analysis was used to confirm that the cells were in osmotic equilibrium in the experimental media. Boar sperm cell volumes were fitted to the following equation (Boyle van't Hoff relationship) to measure the osmotically inactive cell fraction and to determine whether boar spermatozoa behave as linear osmometers:

$$
\frac{V}{V_{\text {iso }}}=\frac{M_{\text {iso }}}{M}\left(1-\frac{V_{\mathrm{b}}}{V_{\text {iso }}}\right)+\frac{V_{\mathrm{b}}}{V_{\text {iso }}}
$$

where $V$ is the cell volume at the osmolality $M, V_{\text {iso }}$ is the cell volume at isosmolality $\left(M_{\text {iso }}\right)$, and $V_{b}$ is the osmotically inactive cell volume (including both cell solids and osmotically inactive water). The linear osmometer hypothesis was examined in the present study by plotting experimentally measured, normalized cell equilibrium volume $\left(V / V_{\text {iso }}\right)$ versus the reciprocal of normalized osmolality $\left(M_{\text {iso }} / M\right)$. Numerical values of all constants and appropriate units are shown in Table 1.

The following equation was used to determine the surface area of boar spermatozoa $\left(156 \mu^{2}\right)$, as previously reported (Du et al., 1994):

Total $A=2 A+2 t(l+w)+\pi[m l \times m d+p l \times p d+t l \times t d]$

Abbreviations used in this equation and sperm dimensions used to calculate the cell surface area are given in Table 2.

Experiment 3: determination of hydraulic conductivity $\left(\mathrm{L}_{p}\right)$. The hydraulic conductivity of boar spermatozoa was determined at $22^{\circ} \mathrm{C}$. After the samples were processed, $100 \mu \mathrm{l}$ of cell suspensions were abruptly diluted into $185 \mathrm{mOsmol} \mathrm{kg}{ }^{-1} \mathrm{TL}$ Hepes media and the resulting kinetic data were recorded. Isosmotic cell volumes were measured before the start of each experiment. The following equation was used to determine the rate of water flux across the cell membrane (Dick, 1966):

$$
\frac{\mathrm{d} V(\mathrm{t})}{\mathrm{dt}}=-L_{\mathrm{p}} A_{\mathrm{c}}\left(C_{\mathrm{salt}}^{\mathrm{e}}-C_{\mathrm{salt}}^{\mathrm{i}}\right) R T
$$


Table 2. Dimensions of boar spermatozoa

\begin{tabular}{lcc}
\hline Variable & Dimension & Reference \\
\hline Head area $(A)$ & $37.6 \mu \mathrm{m}^{2}$ & $\mathrm{I}$ \\
Head length $(l)$ & $8.21 \mu \mathrm{m}$ & 2 \\
Head width $(w)$ & $4.37 \mu \mathrm{m}$ & 2 \\
Head thickness $(t)$ & $0.35 \mu \mathrm{m}$ & 3 \\
Mid-piece length $(m l)$ & $10.6 \mu \mathrm{m}$ & Average from 2 and 3 \\
Mid-piece diameter $(m d)$ & $0.75 \mu \mathrm{m}$ & 3 \\
Principle piece length $(p l)$ & $28.6 \mu \mathrm{m}$ & Average from 2,3 and 4 \\
Principle piece diameter $(p d)$ & $0.5 \mu \mathrm{m}$ & 3 \\
Tail length $(t l)$ & $2.5 \mu \mathrm{m}$ & 3 \\
Tail end diameter $(t d)$ & $0.2 \mu \mathrm{m}$ & Average from 3 and 5
\end{tabular}

${ }^{1}$ Van Duijn, 1960; ${ }^{2}$ Cummins and Woodall, 1985; ${ }^{3}$ Bonet and Briz, 1991; ${ }^{4} \mathrm{H}$ ancock, 1956; and ${ }^{5}$ Bustos-Obregon and Fléchon, 1975.

$$
C_{\mathrm{salt}}^{\mathrm{i}}=C_{\mathrm{salt}}^{\mathrm{i}}(\mathrm{o})\left[\frac{V_{\mathrm{iso}}-V_{\mathrm{b}}}{V_{(\mathrm{t})}-V_{\mathrm{b}}}\right]
$$

where $L_{p}$ is the hydraulic conductivity, $A_{c}=$ sperm surface area, $t=$ time, $C_{\text {salt }}^{\mathrm{e}}$ is the extracellular salt concentration (185 mOsmol kg ${ }^{-1}$ ), $C_{\text {salt }}^{\mathrm{i}}$ is the intracellular salt concentration $\left(285 \mathrm{mOsmol} \mathrm{kg}^{-1}\right), \quad R=$ Universal gas constant, $T=$ absolute temperature and $(0)=$ time zero.

Membrane transport parameters were estimated for the kinetic volume data using the software package SLAB ${ }^{\text {IS }}$ (Civilized Software 1993, Bethesda, MD), which solves differential equations using the Gear method (Press et al., 1992), and iterates the solution to find the best fit parameters using the Marquardt-Levenberg method (Press et al., 1992). Samples from five boars were used.

Experiment 4: effects of osmolality and temperature on sperm motility. Sperm motility was examined after spermatozoa were exposed to various iso- and hyposmotic conditions ranging from 50 to $290 \mathrm{mOsmol} \mathrm{kg}{ }^{-1}$. Two hundred microlitres of the semen sample were added to $\mathrm{I} \mathrm{ml}$ of solutions of $\mathrm{NaCl}$ of various concentrations. The final osmolality ranged from 90 to $286 \mathrm{mOsmol} \mathrm{kg}{ }^{-1}$. After $5 \mathrm{~min}$ in the $\mathrm{NaCl}$ solution, the percentage of motile spermatozoa was determined using CASA by counting at least 240 cells in each osmotic condition. The data from each series were normalized to

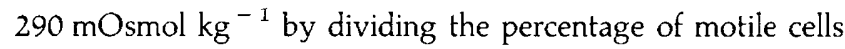
at different osmolalities by the percentage of motile cells at $290 \mathrm{mOsmol} \mathrm{kg}{ }^{-1}$. The effects of temperature were examined either by directly putting the sample tube into a $30^{\circ} \mathrm{C}$ water bath or by slowly cooling the cells to 8 or $0^{\circ} \mathrm{C}$ at $0.2^{\circ} \mathrm{C} \mathrm{min}-1$ for $20 \mathrm{~min}$ using a programmable cooling freezer (Planer Products Ltd, Perkasie, PA). Samples were then left on the bench top to warm to room temperature, and motility was assessed. Samples from six boars were used.

Experiment 5: effects of osmolality on membrane integrity and the temperature dependence of these effects. The osmolality at which $50 \%$ of the spermatozoa swell and lyse (critical osmolality) was determined. The range of osmolalities examined was
290-3 mOsmol kg- ${ }^{-1}$. Aliquots of the sperm samples were first equilibrated at $290 \mathrm{mOsmol} \mathrm{kg}{ }^{-1}$ in the following conditions: (1) at $30^{\circ} \mathrm{C}$ (water bath); (2) at $22^{\circ} \mathrm{C}$ (room temperature); (3) at $8^{\circ} \mathrm{C}$ (spermatozoa were cooled to the desired temperature at the rate of $0.2^{\circ} \mathrm{C} \mathrm{min}{ }^{-1}$ ); and (4) at $0^{\circ} \mathrm{C}$ (spermatozoa were cooled to the desired temperature at the rate of $0.2^{\circ} \mathrm{C} \mathrm{min}^{-1}$ ). At each temperature, $10 \mu \mathrm{l}$ of the sperm suspension (approximately $0.5-1 \times 10^{6}$ cells) were first added to $790 \mu$ l isosmotic or different hyposmotic solutions for $5 \mathrm{~min} ; 5 \mu \mathrm{l}$ of $\mathrm{H} 258$ were added to determine the integrity of the plasma membrane. After $5 \mathrm{~min}, 30 \mu \mathrm{l}$ STDNA was applied to remove unbound H258 from the solution to stop the viability staining before returning to isosmotic condition. Finally, $200 \mu \mathrm{l}$ of various concentrations of $\mathrm{NaCl}$ were added to the relevant sperm suspensions to bring the osmolality back to isosmolality. Samples from seven boars were used.

Experiment 6: comparison of the integrity of the sperm membrane before and after returning to isosmolality. Lysis of the sperm plasma membrane that occurs during the hyposmotic shock and during the time when the spermatozoa were returned to isosmolality was investigated. One aliquot was processed as indicated in Expt 5. Ten microlitres of sperm suspension were mixed with $790 \mu \mathrm{l}$ of isosmotic or hyposmotic solutions, range $0-288 \mathrm{mOsmol} \mathrm{kg}{ }^{-1}$ to form the final concentration range of $3-290 \mathrm{mOsmol} \mathrm{kg}{ }^{-1}$. After 2 min, $5 \mu \mathrm{l}$ of $\mathrm{H} 258$ was added followed by $30 \mu \mathrm{l}$ of STDNA to adsorb unbound H258. After $3 \mathrm{~min}, 200 \mu \mathrm{l}$ of recovery medium were added to bring the sperm suspension back to an isosmotic condition. Another aliquot was used to expose spermatozoa to isosmotic or hyposmotic conditions for $5 \mathrm{~min}$, followed by adding relevant $200 \mu \mathrm{l}$ recovery $\mathrm{NaCl}$ solution to bring the osmolality back to an isosmotic condition. After 2 min, $5 \mu$ of $\mathrm{H} 258$ were added and after $5 \mathrm{~min} 30 \mu \mathrm{l}$ of STDNA was used to exclude the unbound H258. Samples from six boars were used.

\section{Results}

\section{Experiment 1: determination of isosmotic cell volume of boar spermatozoa}

The isosmotic volume of boar spermatozoa was determined at $22^{\circ} \mathrm{C}$. The mean ( \pm SEM) cell volume was $26.3 \pm 0.39 \mu \mathrm{m}^{3}$, with no significant difference among donors (among semen samples from the same donor) $(P>0.10)$. However, there was a main effect of donor (among different donors) $(P<0.05$ ). The variability among and within donors was small, with a coefficient of variation (CV) for each of less than $6.0 \%$.

\section{Experiment 2: cell osmotic response and inactive cell volume $\left(\mathrm{V}_{b}\right)$}

The osmotic response of boar spermatozoa was determined over the range $185-900 \mathrm{mOsmol} \mathrm{kg}{ }^{-1}$ at $22^{\circ} \mathrm{C}$. Data are presented as a Boyle van't Hoff plot (volume versus 1/osmolality) and illustrates a linear response $\left(r^{2}=0.99\right)$ within this osmotic range and a $V_{b}$ of $67.4 \pm 4.5 \%$ (Fig. 1). The $\mathrm{CV}$ for $V_{\mathrm{b}}$ among donors was $14.9 \%$. 


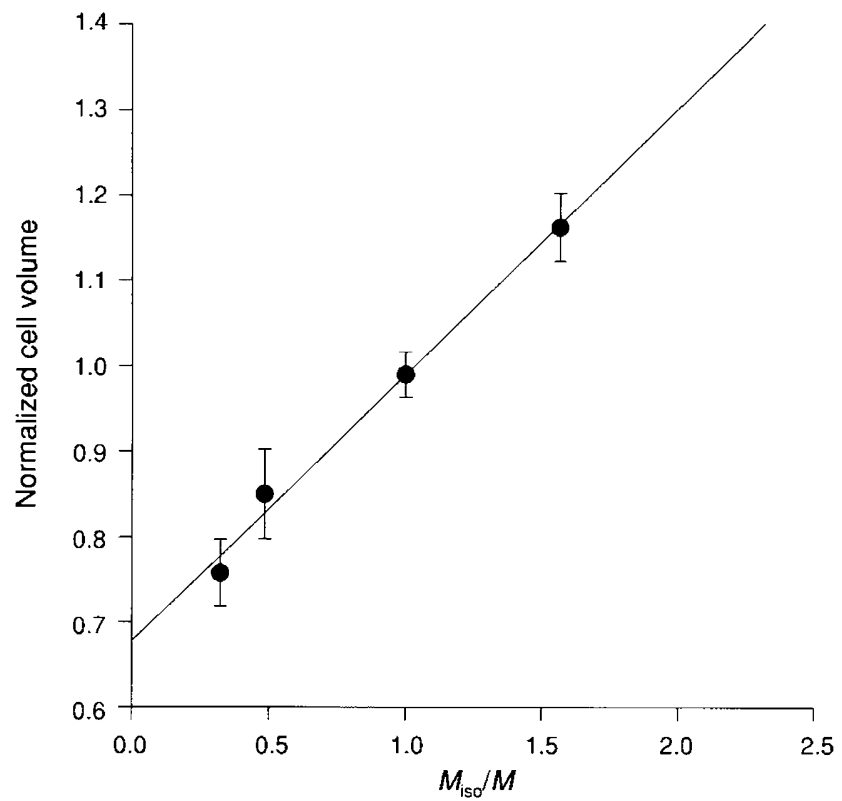

Fig. 1. Boyle van't Hoff plot (volume versus reciprocal of osmolality) of boar spermatozoa at $22^{\circ} \mathrm{C}$. Sperm samples (mean \pm SEM) $(n=5)$ were exposed to four different osmolalities: (1) $900 \mathrm{mOsmol} \mathrm{kg}^{-1}$, (2) $600 \mathrm{mOsmol} \mathrm{kg}^{-1}$, (3) $285 \mathrm{mOsmol} \mathrm{kg} \mathrm{kg}^{-1}$ and (4) $185 \mathrm{mOsmol}$ $\mathrm{kg}^{-1}$. There was a $3 \mathrm{~min}$ osmotic equilibration time before analysis.

\section{Experiment 3: determination of hydraulic conductivity $\left(\mathrm{L}_{p}\right)$}

Data from the changes in boar sperm cell volume in $185 \mathrm{mOsmol} \mathrm{kg}{ }^{-1}$ (Fig. 2) were fitted to equation (3) to determine the hydraulic conductivity $\left(L_{\mathrm{p}}\right)$ at $22^{\circ} \mathrm{C}$. The mean ( \pm SEM) $L_{p}$ value was $1.03 \pm 0.05 \mu \mathrm{m} \mathrm{min}^{-1} \mathrm{~atm}^{-1}$, and there was no significant effect either among or within donors $\left(P=0.14\right.$ and 0.32 , respectively). The CV for $L_{\mathrm{p}}$ was $19.8 \%$ among donors, and $16.7 \%$ within donors.

Experiment 4: effects of osmolality and temperature on sperm motility

Motility appeared to remain constant to $210 \mathrm{mOsmol} \mathrm{kg}{ }^{-1}$, below which motility began to decrease (Fig. 3). Fifty per cent of the cells remained motile at $180 \mathrm{mOsmol} \mathrm{kg}{ }^{-1}$, whereas only $20 \%$ were motile at $90 \mathrm{mOsmol} \mathrm{kg}{ }^{-1}$.

A plot of normalized percentage motility versus temperature illustrates that motility was not affected $(P>0.05)$ when the temperature changed from room temperature, $22^{\circ} \mathrm{C}$, to $30^{\circ} \mathrm{C}$ (Fig. 4). However, motility was markedly reduced $(P<0.05)$ when the temperature was decreased from $22^{\circ}$ to $8^{\circ}$ and $0^{\circ} \mathrm{C}$, even with a relatively slow cooling rate $\left(0.2^{\circ} \mathrm{C} \mathrm{min}^{-1}\right)$.

Experiment 5: effects of osmolality on membrane integrity and temperature dependence of these effects

The normalized percentages of boar spermatozoa with intact plasma membrane after exposure to isosmotic and various hyposmolalities at temperatures of $30,22,8$, and $0^{\circ} \mathrm{C}$ are shown (Fig. 5). The loss of integrity of the plasma membrane

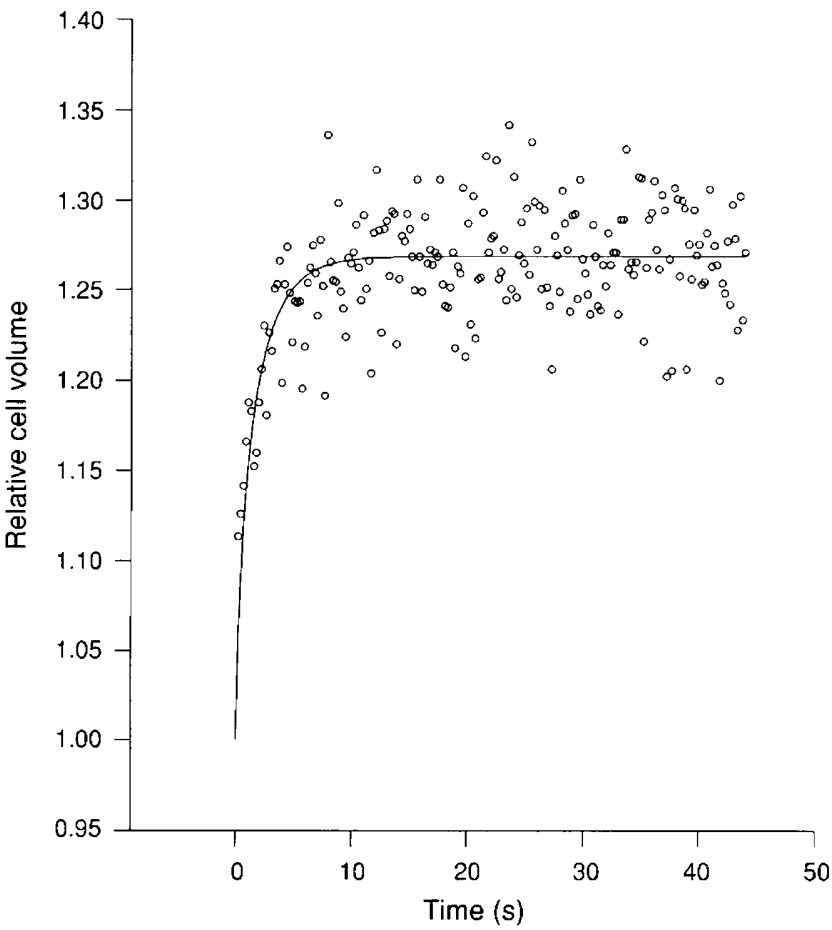

Fig. 2. Kinetic volume changes during hyposmotic swelling of boar spermatozoa at $22^{\circ} \mathrm{C}$. The isosmotic cell samples were abruptly diluted into $185 \mathrm{mOsmol} \mathrm{kg}{ }^{-1}$ and the average cell volume was measured over time. A mass transfer model was applied to fit the experimental data and to determine the hydraulic conductivity $\left(L_{p}\right)$ value $(n=5)$.

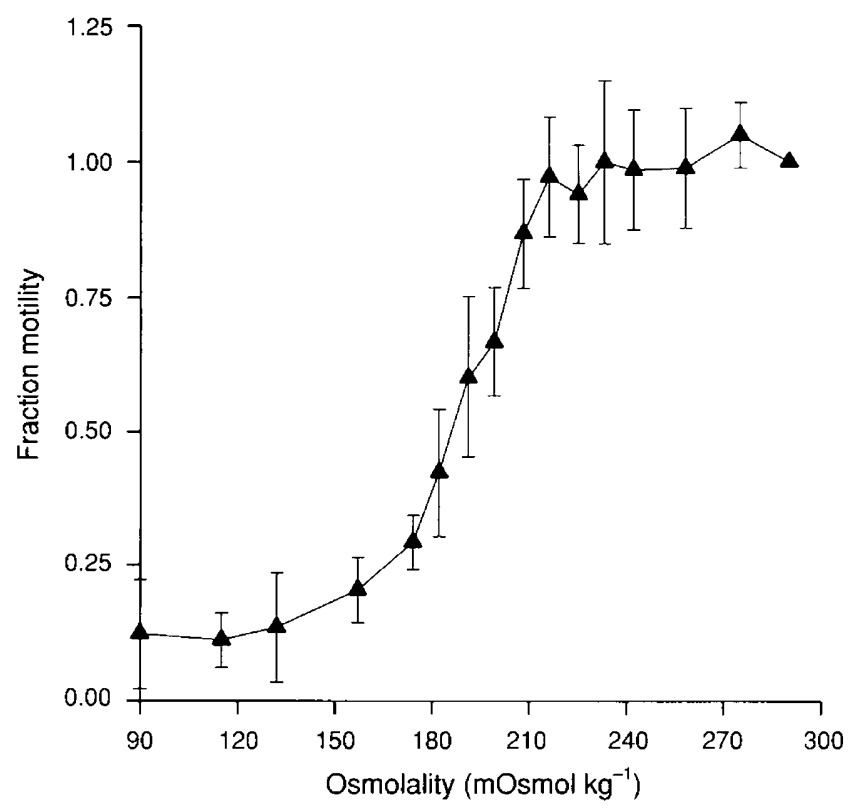

Fig. 3. The effects of osmolality on the normalized motility of boar spermatozoa (mean $\pm \operatorname{SEM})(n=6)$ were measured over the osmotic range of $90-300 \mathrm{mOsmol} \mathrm{kg}^{-1}$.

was different $(P<0.05)$ among donors at given osmolalities, and the loss of integrity was greater $(P<0.05)$ at 8 and $0^{\circ} \mathrm{C}$, compared with that at 22 and $30^{\circ} \mathrm{C}$. 


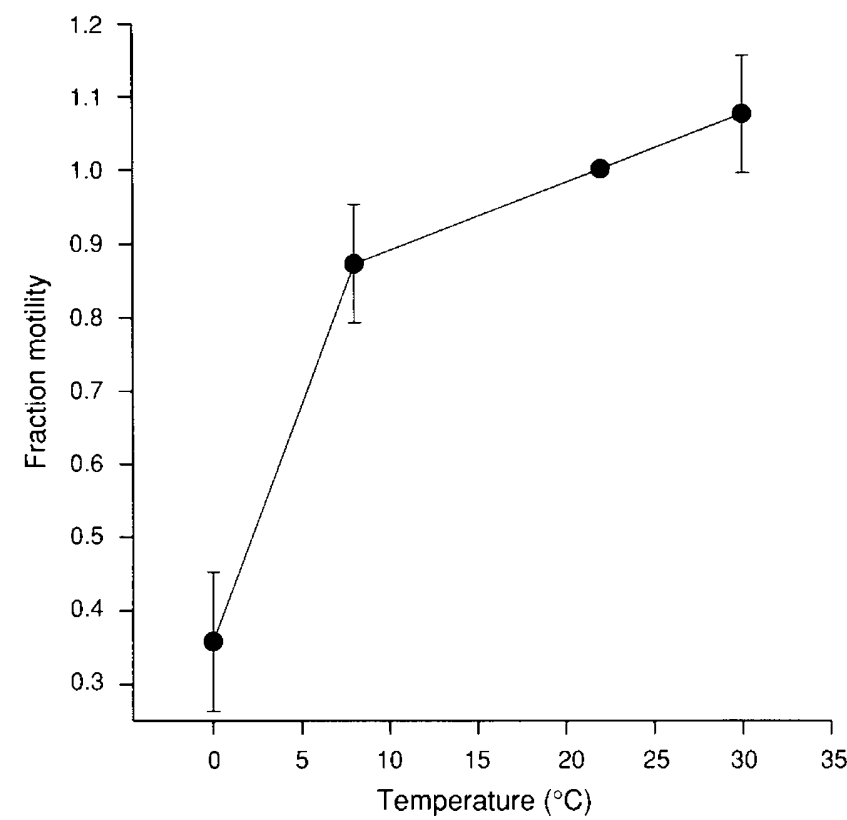

Fig. 4. The effects of temperature on the normalized motility of boar spermatozoa (mean $\pm \mathrm{SEM})(n=6)$ were measured over the temperature range of $0-35^{\circ} \mathrm{C}$.

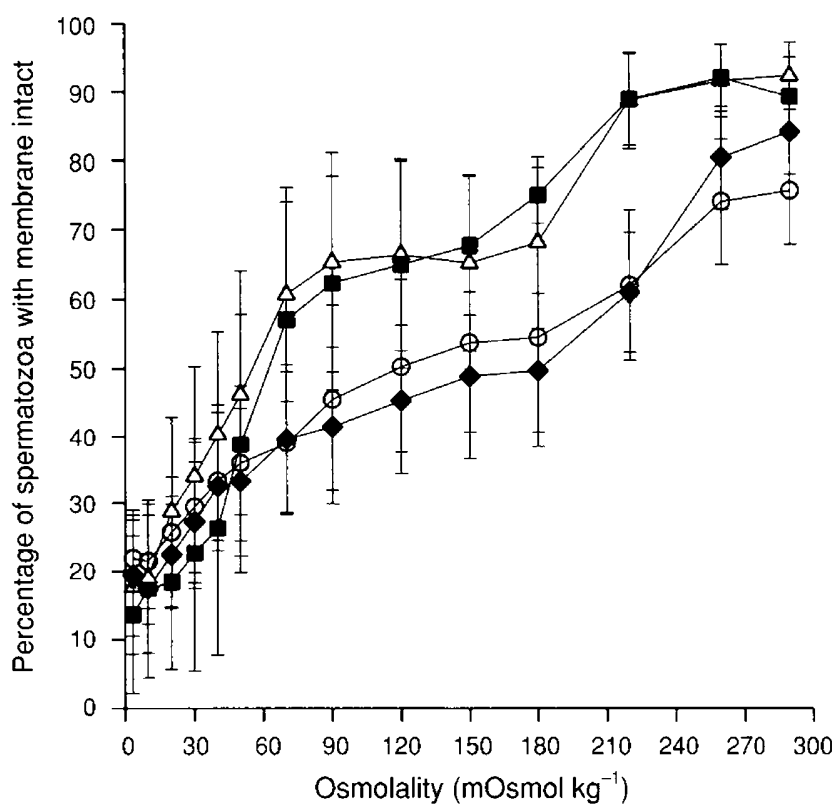

Fig. 5. The effects of osmolality on the plasma membrane of boar spermatozoa and its temperature dependence were measured at (a) $30^{\circ} \mathrm{C},(\triangle) 22^{\circ} \mathrm{C},(\diamond) 8^{\circ} \mathrm{C}$ and $(\curvearrowright) 0^{\circ} \mathrm{C}$ (mean \pm SEM) $(n=7)$.

Experiment 6: comparison of sperm membrane integrity before and after returning to isosmotic condition

There was no significant difference $(P>0.10)$ in plasma membrane integrity among samples before and after returning

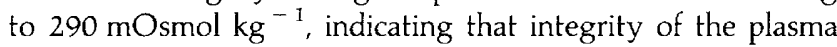
membrane is lost before returning to the isosmotic condition (Fig. 6).

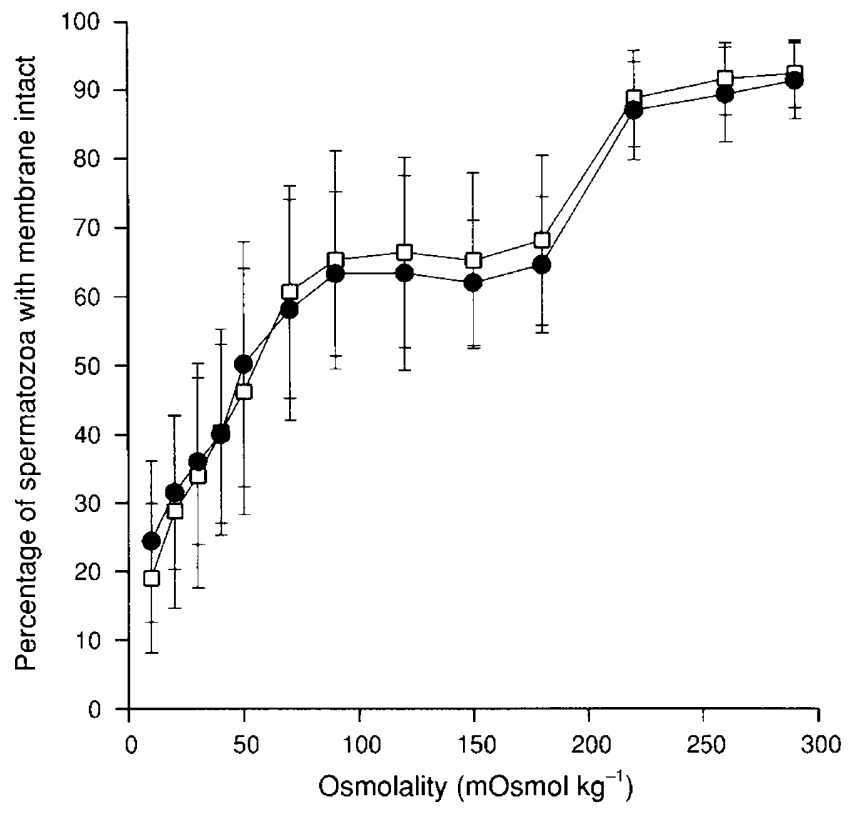

Fig. 6. The integrity of membrane of boar spermatozoa was measured before and after returning the cells to an isosmotic condition. ( $\square$ ) Salmon testis DNA was added after the cells were exposed to a hyposmotic media. (-) Samples were returned to isosmotic media before the integrity of the membrane was evaluated (mean \pm SEM) $(n=6)$.

\section{Discussion}

The water volume of boar spermatozoa is in the range of $18.4 \mu^{3}$ (Du et al., 1994) to $20 \mu^{3}$ (Hammerstedt et al., 1978), as determined using electron paramagnetic resonance. Du et al. (1994) estimated a total isosmotic cell volume of $22.0-25.4 \mu \mathrm{m}^{3}$. O'Donnell (1969) measured an isosmotic cell volume of $21 \mu \mathrm{m}^{3}$ using an electronic particle counter. These values are similar to the mean isosmotic cell volume of $26.6 \mu \mathrm{m}^{3}$ reported in this study.

Boar spermatozoa behave as linear osmometers in the range 210-1500 mOsmol kg-1, with a relatively large percentage $\{23 \%$ ) of the water being osmotically inactive (Du et al., 1994). The present study confirms these findings and extends the linear osmotic behaviour down to $185 \mathrm{mOsmol} \mathrm{kg}^{-1}$, with $67 \%$ of the total cell volume (both solids and water) being osmotically inactive.

Knowledge of the osmotically inactive fraction of boar sperm cells aids in determining the optimal approach for cryopreservation. The portion of the cell water that is osmotically active (that is, will cross the cell plasma membrane during osmotically driven cell volume changes) can be identified. This osmotic characteristic can be combined with knowledge regarding the volume changes that the cells can endure during addition and removal of cryoprotectant and the freezing and warming processes and can therefore be used to limit osmotic stresses during cryopreservation (Gao et al., 1995).

Previous studies have determined the water content of boar spermatozoa and the total content of the cells. However, there has not been a technique to determine the solids content of boar sperm cells successfully. By combining the $V_{b}$ from the current data, and the previous EPR-derived water volume $\left(V_{w}\right)$ 
Table 3. Hydraulic conductivities at room temperature of reproductive cell types

Hydraulic conductivity
$\left(\mu \mathrm{m} \min ^{-1} \mathrm{~atm}^{-1}\right)$

$\begin{array}{lc}\text { Human spermatozoa }^{\mathrm{a}} & 1.8 \\ \text { Human spermatozoa }^{\mathrm{b}} & 2.4 \\ \text { Fowl spermatozoa }^{c} & 2.1 \\ \text { Bull spermatozoa }^{\mathrm{c}} & 10.8 \\ \text { Rabbit spermatozoa }^{\mathrm{d}} & 0.63 \\ \text { Fertilized mouse ova }^{\mathrm{e}} & 0.43 \\ \text { Unfertilized mouse ova }^{\mathrm{e}} & 0.44 \\ \text { Unfertilized golden hamster oocytes }^{\mathrm{f}} & 0.45 \\ \text { Unfertilized ICR mouse oocytes }^{\mathrm{f}} & 0.40\end{array}$

${ }^{3}$ Gilmore et al., 1995; ' Noiles et al., 1993; 'Watson et al., 1992; 'Curry et al., 1995; 'Leibo, 1980; and 'Benson and Critser, 1994.

of $\mathrm{Du}$ et al. (1994), it is now possible to determine the volume of solids $\left(V_{\mathrm{s}}\right)$ of boar spermatozoa. The study reported here estimated a $V_{\mathrm{b}}$ value of $67 \%$ at $22^{\circ} \mathrm{C}$, and $\mathrm{Du}$ et al. (1994) determined the Ponder's $R$ (translated from the non-zero $y$ axis intercept) value to be 0.77 .

Using the following equation (Gilmore et al., 1995), the $V_{\mathrm{s}}$ can be determined as follows:

$$
V_{\mathrm{s}}=\frac{V_{\mathrm{b}}(\%)-100 \%(1-R)}{R}
$$

Use of this equation and the data from the present study and that of Du et al. (1994) gives a $V_{\mathrm{s}}$ value of $57 \%$, which is comparable to $42 \%$ found with human spermatozoa (Gilmore et al., 1995).

Little is known regarding the hydraulic conductivity of boar spermatozoa. The study reported here determined the mean rate of water permeation across the boar cell plasma membrane, to be $1.03 \mu \mathrm{m} \mathrm{min}^{-1} \mathrm{~atm}^{-1}$. This value fits well within the range of water permeability rates from spermatozoa of other species (Table 3). Knowledge of the rate of water movement across the sperm plasma membrane, along with other cell parameters, such as the permeability of the permeating solute (that is, cryoprotectant compounds) and the surface area: volume ratio, is essential for determining the optimal rate for adding and removing cryoprotectants and for cooling and warming cells during cryopreservation. The hydraulic conductivity is a value across the entire cell. More investigation is needed to determine whether the permeability is the same over the entire cell or is region specific. The activation energy of $L_{\mathrm{p}}$ is also important for cryopreservation and studies are currently being conducted to determine the temperature dependence of $L_{\mathrm{p}}$ for boar spermatozoa.

An important factor influencing the rate of water permeability is the presence of cryoprotectants. Gilmore et al. (1995) have recently shown that $L_{\mathrm{p}}$ in human spermatozoa decreases in the presence of cryoprotectants such as glycerol, dimethylsulfoxide, ethylene glycol and propylene glycol. As a result, the rate at which cells should be cooled and warmed is affected (decreased) when using a permeating solute. The hydraulic conductivity of boar spermatozoa reported here may be similarly affected. Ongoing studies are being performed to measure the effect of permeating solutes on the water permeability of the boar sperm plasma membrane and its temperature dependence.

Boar spermatozoa appear to have a relatively low tolerance to hyposmotic conditions. This may be related to the large fraction of the cell that is osmotically inactive. Motility

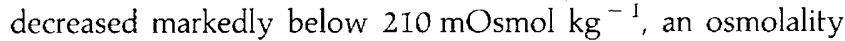
that is only $28 \%$ less than physiological isosmotic conditions $\left(290 \mathrm{mOsmol} \mathrm{kg}{ }^{-1}\right)$. Human spermatozoa also show a significant reduction in motility when osmolalities are decreased by

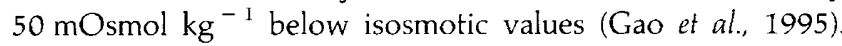
The integrity of boar sperm plasma membrane was not lost in this osmotic transition, indicating that motility is more sensitive to osmotic change than is membrane integrity; this result is also similar to human sperm responses.

Boar spermatozoa are sensitive to cold shock: low temperatures above $0^{\circ} \mathrm{C}$ can induce physical and biological damage to spermatozoa (de Leeuw et al., 1991). This damage can be intensified when using fast cooling rates, resulting not only in loss of motility and plasma membrane integrity, but also a loss in metabolic activity and acrosome function, directly compromising fertility (Foote, 1988). This feature of boar spermatozoa was recognized by Polge (1956), who found that survival of boar spermatozoa is significantly reduced below $15^{\circ} \mathrm{C}$. Sensitivity to cold shock is not unique to boar spermatozoa; Watson and Morris (1987) have reviewed this phenomenon in several animal cells. The present study confirmed this sensitivity in boar spermatozoa by showing that motility decreased markedly with a decrease in temperature. More importantly, this study showed that boar spermatozoa remain sensitive to cold shock even when relatively slow cooling rates $\left(0.2^{\circ} \mathrm{C} \mathrm{min}{ }^{-1}\right)$ are used. In practice, even slower cooling rates are used for cryopreservation of boar spermatozoa (for example, $0.04^{\circ} \mathrm{C} \mathrm{min}^{-1}$; Pursel and Johnson, 1975). This information is important for ongoing work to determine the activation energies for water and cryoprotectant permeabilities of boar spermatozoa.

Boar spermatozoa showed significant loss of plasma membrane integrity over two osmotic regions. The results presented here indicate that the plasma membrane of boar spermatozoa becomes less tolerant to hyposmotic conditions as temperature decreases. A number of studies have been conducted to determine the cause of plasma membrane alteration during cooling processes. Buhr (1991) proposed that the molecular organization, and the ability to reorganize, in the lipid matrix of the plasma membrane is altered by a decrease in temperature. This modification is demonstrated by changes in fluidity, particularly in the plasma membrane of the head and can result in a decrease in $\mathrm{Ca}^{2+}$ responsiveness. It has been shown that boar spermatozoa undergoing cold shock display membrane disruption in calcium movements (Plummer and Watson, 1985). De Leeuw et al. (1991) suggested that there is a large amount of particle aggregation in the heads of boar spermatozoa upon cooling caused by lateral phase separation, and this could be the reason for the high sensitivity to low temperatures.

The current study is one of many studies that are needed to determine the osmotic properties and tolerance limits of boar spermatozoa. Further investigation is ongoing which includes 
exposing boar sperm cells to anisosmotic conditions, both hypo- and hyperosmotic, and returning them to an isosmotic condition. A number of assays are being used to evaluate motility, plasma membrane integrity and acrosome integrity to determine the most sensitive functional endpoint. These data, in combination with the information obtained in this study, will define the osmotic tolerance limits (the degree to which the cells can undergo volume changes and still retain functional integrity) of boar spermatozoa and can be used to determine the optimal rate of freezing and thawing, as well as the most appropriate cryoprotectant type and concentration and the optimal approach of addition and removal for cryopreservation.

The results of this study indicate a greater loss in boar sperm plasma membrane integrity with a decrease in temperature. Further studies should be conducted to evaluate the mechanism of this response to low temperatures which may also lead to a further understanding of the causes of sensitivity to cold shock.

The results reported here indicate that plasma membrane integrity was lost during the transition from isosmotic to anisosmotic conditions. The damage was already present before the cells were returned to $290 \mathrm{mOsmol} \mathrm{kg}{ }^{-1}$. In cryobiological terms, this would mean that cells would lose plasma membrane integrity during the processes of exposure to hyposmotic conditions (that is, the higher intracellular osmolality that occurs during the warming stages of cryopreservation). With this information, steps to eliminate cell lysis can be taken. These might include, for example, the addition of hyperosmotic media after the cells have been warmed and exposed to hyposmotic conditions; this would reduce the change in cell volume (Gao et al., 1995).

Overall, this study has determined several cryobiologically important cell characteristics of boar spermatozoa that can be directly applied to the improvement of cryopreservation protocols. These results indicate that: (1) boar spermatozoa exhibit a linear osmotic response in the range of 185-900 mOsmol kg ${ }^{-1}$; (2) low temperatures and low osmolalities decrease sperm motility and plasma membrane integrity and osmotic damage is accrued during the transition from isosmotic to anisosmotic states; and (3) the magnitude of osmotic responses found in boar spermatozoa depend on the rate of water permeation across the cell plasma membrane and resulting volume changes. This knowledge can be combined with information regarding other cryobiologically important cell characteristics such as solute permeability and their activation energies. Optimal procedures for the cryopreservation of boar spermatozoa can then be developed which prevent damage of the sperm plasma membrane and other necessary structures which influence vital endpoints such as motility and internal membrane-bound structure functions (such as the acrosome), and therefore, ensure cell survival during the cooling and warming stages of cryopreservation.

The authors would like to thank L. McGann (Department of Laboratory Medicine and Pathology, University of Alberta), P. Watson (Royal Veterinary College, University of London) and F. W. Kleinhans (Department of Physics, Indiana University-Purdue University Indianapolis) for helpful discussions of the manuscript, and $\mathrm{K}$. Vernon for assistance with manuscript preparation. This work was supported by a grant from USDA/NRI Competitive Grants Program
(93-37203-9272), by a Career Development Award from the NIH (K04-HD00980 to J. K. Critser) and by a NATO Collaborative Research Grant (CGR 920170).

\section{References}

Bavister BD, Leibfried ML and Lieberman G (1983) Development of preimplantation embryos of the golden hamster in a defined culture medium Biology of Reproduction 28 235-247

Benson CT and Critser JK (1994) Variation of water permeability $\left(\mathrm{L}_{\mathrm{p}}\right)$ and its activation energy $\left(E_{a}\right)$ among unfertilized golden hamster and ICR murine oocytes Cryobiology 31 215-223

Bonet S and Briz M (1991) New data on aberrant spermatozoa in the ejaculate of Sus domesticus Theriogenology 35 725-730

Buhr MM (1991) Preservation of boar sperm alters membrane molecular dynamics. In Boar Semen Preservation II. Proceedings of the Second International Conference on Boar Semen Preservation held at Beltsville, Maryland, USA, August 1990 pp 81-93 Eds LA Johnson and D Rath. Paul Parey Scientific Publishers, Berlin and Hamburg

Bustos-Obregon E and Fléchon JE (1975) Comparative scanning electron microscope study of boar, bull and ram spermatozoa Cell and Tissue Research 161 329-341

Cummins JM and Woodall PF (1985) On mammalian sperm dimensions Journal of Reproduction and Fertility 75 153-175

Curry MR, Redding BJ and Watson PF (1995) Determination of water permeability coefficient and its activation energy for rabbit spermatozoa Cryobiology 32 175-181

de Leeuw FE, Colenbrander B and Verkleij AJ (1991) The role membrane damage plays in cold shock freezing and injury. In Boar Semen Preservation II. Proceedings of the Second International Conference on Boar Semen Preservation held at Beltsville, Maryland, USA, August 1990 pp 95-104 Eds LA Johnson and D Rath. Paul Parey Scientific Publishers, Berlin and Hamburg

Dick DAT (1966) Cell Water pp 85-89. Butterworths, Washington

Du Junying, Tao Jun, Kleinhans FW, Peter AT and Critser JK (1994) Determination of boar spermatozoa water volume and osmotic response Theriogenology 42 1183-1191

Foote RH (1988) Preservation and fertility predictions Proceedings of the 11th International Congress of Animal Reproduction and Artificial Insemination, Dublin 5 127-134

Gao DY, Liu J, Liu C, McGann LE, Watson PF, Kleinhans FW, Mazur P, Critser ES and Critser JK (1995) Prevention of osmotic injury to human spermatozoa during addition and removal of glycerol Human Reproduction 10 1109-1122

Gilmore JA, McGann LE, Liu J, Gao DY, Peter AT, Kleinhans FW and Critser JK (1995) Effect of cryoprotectant solutes on water permeability of human spermatozoa Biology of Reproduction 53 985-995

Hammerstedt RH, Keith AD, Snipes W, Amman RP, Arruda D and Griel Jr LC (1978) Use of spin labels to evaluate effects of cold shock and osmolality on sperm Biology of Reproduction 18 686-696

Hancock JL (1956) The morphology of boar spermatozoa Journal of the Royal Microscopical Society $76 \quad 84-97$

Hofmo PO and Almlid T (1991) Recent developments in freezing of boar semen with special emphasis on cryoprotectants. In Boar Semen Preservation II. Proceedings of the Second International Conference on Boar Semen Preservation held at Beltsville, Maryland, USA, August 1990 pp 111-122 Eds LA Johnson and D Rath. Paul Parey Scientific Publishers, Berlin and Hamburg

Ito S, Niwa T, Kudo A and Mizuho A (1948) Studies on the artificial insemination in swine Chiba Zootechnical Experimental Station Research Bulletin 55 1-74

Johnson LA, Aalbers JG, Willems CMT and Sybesma W (1981) Use of boar spermatozoa for artificial insemination. I. Fertilizing capacity of fresh and frozen spermatozoa in sows on 36 farms Journal of Animal Science 52 $1130-1136$

Leibo SP (1980) Water permeability and its activation energy of fertilized and unfertilized mouse ova Membrane Biology 53 179-188

Massanyi L (1989) Computerized evaluation of the motility of boar sperm Veterinari Medicina (Praha) 34 163-170

Noiles EE, Mazur P, Watson PF, Kleinhans FW and Critser JK (1993) Determination of human sperm water permeability Biology of Reproduction $\mathbf{4 8}$ 99-109

O'Donnell JM (1969) Electronic counting and sizing of mammalian spermatozoa and cytoplasmic droplets Journal of Reproduction and Fertility 19 263-272 
Plummer JM and Watson PF (1985) Ultrastructural localization of calcium ions in ram spermatozoa before and after cold shock as demonstrated by a pyrantimonate technique Journal of Reproduction and Fertility $\mathbf{7 5}$ 255-263

Polge $C$ (1956) Artificial insemination in pigs Veterinary Record 68 62-76

Pond WG, Maner JH and Harris DL (1991) Pork Production Systems: Efficient Use of Swine and Feed Resources. Van Nostrand Reinhold, New York

Press WH, Teukolsky SA, Vetterling WT and Flannery BP (1992) Numerical Recipes in Fortran: The Art of Scientific Computing (2nd Edn) pp 727-730. Cambridge University Press, Cambridge

Pursel VG and Johnson LA (1975) Freezing of boar spermatozoa: fertilizing capacity with concentrated semen and a new thawing procedure Journal of Animal Science 40 99-102

Reed H (1985) Current use of frozen boar semen - future need of frozen boar semen. In Proceedings First International Conference on Deep Freezing of Boar Semen, Uppsala, Sweden, August 1985 pp 225-237 Eds LA Johnson and K Larsson. Swedish University of Agricultural Sciences, Uppsala
Steel RGD and Torrie JH (1960) Principles and Procedures of Statistics pp 194-231. McGraw-Hill, New York

Tao Jun, Critser ES and Critser JK (1993) Evaluation of mouse sperm acrosomal status and viability by flow cytometry Molecular Reproduction and Development 115 183-194

Van Duijn C Jr (1960) Mensuration of the heads of boar spermatozoa Mikroskopie 14 256-276

Watson PF and Morris GJ (1987) Cold shock injury in animal cells. In Temperature and Animal Cells. Society of Experimental Biology Symposium No. 41 pp 331-340 Eds K Bowler and BJ Fuller. The Company of Biologists Limited, Cambridge

Watson PF, Kunze E, Cramer P and Hammerstedt RH (1992) A comparison of critical osmolality and hydraulic conductivity and its activation energy in fowl and bull spermatozoa Journal of Andrology 13 131-138

Westendorf $\mathbf{P}$, Richter $\mathbf{L}$ and Treu $\mathrm{H}$ (1975) Zur Tiefgefrierung von Ebersperma. Labor- und Besamungsergebnisse mit dem Hulsenberger PaillettenVerfahren Deutsche Tierarztliche Wochenschrift 82 261-267 